\title{
Habitual Activity in Pre-industrial Rural and Urban Dutch Populations: A Study of Lower Limb Cross-sectional Geometry
}

Jaap P. P. Saers, ${ }^{a} *$ Menno L. P. Hoogland, ${ }^{\mathrm{b}}$ Rick R. van Rijn, ${ }^{\mathrm{c}}$ Rachel Schats, ${ }^{\mathrm{b}}$ A. E. van der Merwe, ${ }^{\mathrm{d}}$ and Andrea L. Waters-Rist ${ }^{\mathrm{b}}$

${ }^{a}$ PAVE Research Group, Department of Archaeology and Anthropology, Division of Biological Anthropology, University of Cambridge, Pembroke Street, Cambridge, UK

${ }^{\mathrm{b}}$ Faculty of Archaeology, Laboratory for Human Osteoarchaeology, Leiden University, Leiden, the Netherlands cDepartment of Radiology, Academic Medical Centre, University of Amsterdam, Amsterdam, the Netherlands

${ }^{\mathrm{d}}$ Department of Anatomy, Embryology and Physiology, Academic Medical Centre, University of Amsterdam, Amsterdam, the Netherlands

*Correspondence to: J. P. P. Saers, Downing College, Regent Street, CB2 1DQ, Cambridge, UK email: jpps2@cam.ac.uk

\section{ABSTRACT}

This study combines historical data and the principles of bone functional adaptation to examine variation in terrestrial mobility in men and women from pre-industrial urban (Alkmaar 7M, 9F) and rural (Klaaskinderkerke 12M, 8F; Middenbeemster 21M, 22F) Dutch populations. Cross-sectional properties of the femoral and tibial midshaft are determined to investigate variation in lower limb mechanical loading. All populations had comparable age ranges. Rural Middenbeemster males had significantly more elliptically shaped tibiae compared to the other populations. Rural males from Klaaskinderkerke had significantly greater femoral cross-sectional area and torsional rigidity compared to females. In the tibia, the males from both rural populations had greater torsional rigidity and cross-sectional area compared to females. In the rural Middenbeemster population the males also had significantly more elliptically shaped tibiae compared to females. While no sexual dimorphism was found in the urban Alkmaar, significantly greater variation in lower limb cross-sectional properties was found for both males and females relative to the rural populations. These results conform to predictions based on the historical literature of greater lower limb loading in rural males compared to females as well as a greater variety of tasks performed in urban environments. The lack of significant differences in lower limb torsional rigidity or shape between populations in either sex suggests that rural life was not necessarily more physically strenuous than urban life in pre-industrial Dutch populations. However, variation in sexual dimorphism suggests that labor between males and females was differently organized in the rural and urban samples.

Keywords: cross-sectional geometry; sexual dimorphism; the Netherlands 
The transition from rural to urban living marked a fundamental shift in many aspects of human culture, demography, and behavior (Hohenberg 1995). In terms of behavior, the transition from foraging to agriculture and finally to urban life has resulted in a significant reduction in terrestrial mobility, culminating in extremely sedentary lifestyles in modern industrial populations (Ruff 2008; Ruff et al. 2015). The study of long bone diaphyseal cross-sectional geometric properties has been used extensively to assess the effects of large-scale changes in subsistence economy in past human populations (Bridges 1989; Holt 2003; Marchi et al. 2011; Ruff 1987; Stock and Pfeiffer 2001). Cross-sectional geometry has rarely been used to study variation in behavior within generally sedentary populations, as it may not provide adequate resolution to examine minor differences in habitual behavior (Macintosh et al. 2014; Pomeroy 2013; Sparacello et al. 2011). However, within a generally sedentary context, there are potential differences between urban and rural populations in the physical demands of daily activities and the way in which labor is organized between men and women that are worth exploring. This study investigates variation in terrestrial mobility in urban and rural pre-industrial Dutch populations by examining variation in lower limb cross-sectional geometry.

\section{Archaeological and Historical Context}

The popular image of the medieval European city is that of a crowded, unsanitary, and diseaseinfested place (Hohenberg 1995; Schats 2016). Sewage systems were rare, and streets were often full of dirt, garbage, and human waste (de Feo et al. 2014). The inhabitants of the city largely engaged in trade, craft and financial services. The medieval countryside is often described more favorably in terms of health, but people performed backbreaking work on the land with minimal equipment (Hohenberg 1995; Riddle 2008). Thus, the pressures of living in overcrowded and unsanitary urban centers are generally thought to differ significantly from those in small rural communities in terms of disease burden, diet, and day-to-day activities (Budnik and Liczbińska 2006; Lewis 2002). The socioeconomic aspects of the medieval transition from rural to urban living, such as increased population density and commercialization of agriculture, have been extensively studied from a historical perspective (Fields 1999; Hohenberg 1995). Bio archaeological studies investigating the effects of urbanization on past human health and mortality overall find significant differences between rural and urban populations. Redfern et al. (2015) found significantly higher mortality risk for subadults in urban compared to rural populations from Roman Britain. Additionally, they found higher frequencies of enamel hypoplasia, caries, and rickets in adults from urban populations. Studies on later historical periods have also found higher rates of metabolic and infectious disease in urban environments (Harrison and Gibson 1976; Roberts and Cox 2003; Waldron 1989). However, in a study of 30 Late Roman settlements, Pitts and Griffin (2012) found that urban populations exhibited better health than their non-urban contemporaries, indicating that the disadvantages associated with living in urban settlements are not universal. Recent osteoarchaeological work has demonstrated that in pre-industrial Dutch populations, variation in health between urban and rural populations were not as pronounced as the popular image of the Middle Ages suggests (Schats 2016). Although evidence for tuberculosis was present in urban Dutch individuals, most likely as a result of more crowded living conditions, prevalence of nonspecific indicators of stress did not differ between urban and rural Dutch populations. Thus, skeletal indicators of stress suggest that although life in pre-industrial Dutch urban centers may have differed in some ways, it was not necessarily more or less stressful than living in the countryside (Schats 2016). While life in either environment may not have been differentially stressful, there are potential differences between urban and rural populations in the demands of daily physical activities and the way in which labor was organized.

Three pre-industrial Dutch samples are examined: the rural villages of Middenbeemster (A.D. 18291866) and Klaaskinderkerke (A.D. 1286-1570) and the late-medieval city of Alkmaar (A.D. 14481572) (Figure 1). All populations are derived from a small geographic area in the western Netherlands, providing an excellent opportunity to study variation in behavior while limiting the effects of genetic variation, climate, diet, and terrain. Most individuals in the rural Middenbeemster 
cemetery, within the large Beemster polder, were interred between 1829 and 1866 (Lemmers et al. 2013).

The polder is characterized by a small, central village, Middenbeemster, with small hamlets in the west, north (noord), and south (zuid) and farmsteads spread out in area of over $70 \mathrm{~km} 2$. Travel occurred on foot between the farmsteads, hamlets, and central village, where the school, main market, and other central facilities were located (Falger et al. 2012). Technological advances of the Industrial Revolution did not reach the Netherlands until after the cemetery ceased being used (de Jong et al. 1998; Drukker and Tassenaar 1997). This rural community was focused around cattle farming (Falger et al. 2012), and osteoarchaeological research suggests a physically strenuous life for both men and women (Lemmers et al. 2013; Palmer et al. 2014; Saers 2012; Vikatou et al. 2017, submitted manuscript). In nineteenth-century Netherlands a somewhat rigid sexual division of labor was the norm; in the Beemster region, men typically worked out- doors in the pastures and women typically worked in and around the house, milking cows, churning butter, making cheese, preparing meals, sewing and washing clothing, and tending to other household chores and children (Falger et al. 2012; van Cruynin- gen 2005; van Nederveen Meerkerk 2015; van Poppel et al. 2009). However, it was common for women to work in the pastures when necessary, with child care and household tasks left to older children and grand- mothers (Lindeboom et al. 2012). Research suggests men most often traveled - likely to local, rural and sometimes urban community centers - with products to be sold for entry into the market economy (Palmer et al. 2014; Vikatou et al. 2017, submitted manuscript). In the nineteenth century, individuals from all economic and social strata could be found in the Beemster region, but the vast majority were middle class (de Jong et al. 1998), suggesting there should not be major differences in the gendered activity patterns of most citizens, a finding reached by other osteoarchaeo- logical investigations (Lemmers et al. 2013; Palmer et al. 2014; Saers 2012; Vikatou et al. 2017, submitted manuscript). The rural village of Klaaskinderkerke was located in the southwest of the Netherlands in the current province of Zeeland, on the island Schouwen-Duiveland (Trimpe Burger and Huizinga 1964). There is limited information on the village of Klaaskinderkerke; however, more general historical data on Zeeland provide insight into rural life in the late-medieval period. While pastoral farming, especially of sheep, was important in the tenth and eleventh centuries, the focus shifted toward the cultivation of labor-intensive crops for the urban centers during the latemedieval period (van Steensel 2012). Although no detailed historical data exist, it is expected that men more commonly worked in the agricultural fields, while women were more concerned with tasks in and around the house and activities associated with food production such as baking bread and brewing beer (Kaptein 2007). Another common task of rural women was the spinning of wool and linen (Kaptein 2007). In addition to agriculture, the extraction of peat (moernering) from underneath the clay was one of the main, most likely male, activities in the countryside of Zeeland (Leenders 1999, 2004; van Steensel 2012). Furthermore, sea fishing, for herring and other fish, became another significant activity for villagers in Zeeland from the thirteenth century onward (Bennema and Rijnsdorp 2015; Unger 1978; van Steensel 2012). The individuals from urban Alkmaar were buried in a cemetery belonging to a Franciscan monastery. This monastery was founded in A.D. 1448 in the northern part of the town (Alders 2009; Bruinvis 1893; Hakvoort et al. 2015). In total, 189 primary inhumations were excavated from this site (Schats 2016). In the late-medieval period, Alkmaar was a town with approximately eight thousand inhabitants (Kaptein 2007; Lucassen 2002). The occupations in Alkmaar were quite varied but highly specialised (Hoppenbrouwers 2001). While the large-scale textile companies decreased in Alkmaar in the sixteenth century, an increase was noted in traders/craftsmen such as bakers, tailors, shoemakers, and smiths, but also weavers and shipbuilders who were organized in guilds (Kaptein 2007). Although both men and women were often employed in the urban industries, many urban women were probably working from home or entered household service (Jewell 2007). 


\section{Cross-sectional Geometry}

Numerous studies have demonstrated the responsive- ness of long bone diaphyses to habitual loading (Judex et al. 1997; Marchi and Shaw 2011; Pearson and Lieberman 2004; Ruff et al. 2006; Shaw and Stock 2009b; Sugiyama et al. 2010). Long bone midshaft diaphyseal cross sections vary in size and shape to accommodate the loadings placed upon them during life, particularly during adolescence (Pearson and Lieberman 2004; Ruff 2008; Ruff et al. 2006). Beam models are used to quantify the cross-sectional geometric properties of long bones (Ruff 2008). Compressive strength is estimated through cross-sectional area (CSA), bending rigidity is estimated by calculating second moments of area (I), and torsional rigidity can be quantified through the polar second moment of area (J). The distribution of bone throughout the cross section is measured through ratios of anteroposterior to mediolateral bending rigidity (Ix/Iy) and maximum to minimum bending rigidity (Imax/Imin) (Ruff 2008).

Cross-sectional geometry of long bone diaphyses has been used extensively to investigate habitual behavior in past populations (Bridges 1989; Holt 2003; Macintosh et al. 2014; Marchi 2008; Marchi et al. 2006; Ruff et al. 2015; Shaw and Stock 2013; Stock and Pfeiffer 2001). While caution is certainly recommended when inferring loading history from diaphyseal shape and rigidity (Lieberman et al. 2004; Pearson and Lieberman 2004; Ruff et al. 2006; Wallace et al. 2014), numerous studies have demonstrated the responsiveness of limb bone diaphyses to the direction and intensity of loading (Haapasalo et al. 2000; Nikander et al. 2006; Shaw and Stock 2009a, 2009b; Trinkaus et al. 1994). Some caveats should be considered when at- tempting to infer past behavior from long bone morphology. The lower limbs are loaded dynamically from various directions during the gait cycle (Demes 2007; Demes and Carlson 2009; Pearson and Lieberman 2004). Pearson and Lieberman (2004) argue that the neutral axis of bending measured using strain gauges often poorly correlates with the maximum bending rigidity calculated from cross-sectional properties. However, work on modern athletes does suggest that there is a strong correspondence between cross-sectional shape and rigidity and strenuous habitual activities performed during life (Niinimäki et al. 2017; Shaw and Stock 2009a, 2009b). Bone responses to loading vary substantially throughout life (Pearson and Lieberman 2004). Before adolescence bone deposition occurs at the mechanically relevant periosteal surface (Garn 1970; Gosman et al. 2011), while after puberty greater amounts of bone are deposited endosteally (Haapasalo et al. 1998, 2000; Kontulainen et al. 2003). Thus, archaeological trends in lower limb rigidity largely reflect behavior during growth and adolescence. However, the bone structure obtained during growth will be lost if loading patterns in adulthood are not strenuous enough to prevent bone loss (Greendale et al. 1995; Kriska et al. 1988; Ruff et al. 2006; Teegarden et al. 1996). In pre-industrial populations participation in adult behavior often increased at the start of the adolescent growth spurt (Lillehammer 2010; Pearson and Lieber- man 2004; Ruff et al. 2006). Additional factors that are known to influence bone rigidity and geometry include genetics, climate, terrain, diet, and disease (Ruff 2008). Genetic factors have a significant effect on diaphyseal crosssectional morphology (Wallace et al. 2012). Although the rural Middenbeemster sample is more recent than the two medieval samples, no substantial genetic differences are expected between the three groups. The genetic differentiation between subgroups in the modern Dutch population is very small (Lao et al. 2013). The genetic subpopulations identified by Lao et al. (2013) follow a distinctive southeast-to-northwest cline, with the samples analyzed in the current study all belonging to the same geographic subpopulation. A greater extent of genetic variation would be expected in the urban Alkmaar sample compared to the small, rural communities represented by Klaaskinderkerke and Middenbeemster due to the greater size of the urban population. Terrain also has a substantial effect on diaphyseal cross-sectional geometry (Higgins 2014; Marchi et al. 2006; Sparacello and Marchi 2008). However, all three samples come from the western Netherlands and experienced the same annual temperature and flat terrain. Thus, variation in terrain or climate is unlikely to produce any 
variation observed between samples. Potential effects of disease on bone rigidity were limited by choosing specimens with no visible signs of pathology. Additionally, recent work has demonstrated that the prevalence of disease as well as differences in types of conditions differed very little between the urban and rural Dutch populations examined in this article (Schats 2016). While the rural Middenbeemster sample is more recent than the two medieval samples, they relied on similar technology as the rural Klaaskinderkerke for agriculture (de Jong et al. 1998; Drukker and Tassenaar 1997; Falger et al. 2012; van Steensel 2012; Trimpe Burger and Huizinga 1964). Both rural populations had a comparable division of labor, with female economic activities taking place closer to the house and male activities requiring further travel from home (de Jong et al. 1998; Falger et al. 2012; van Steensel 2012; Wintle 2000). In both populations, males were involved in pastoral farming, travel to markets, and extraction of peat (Falger et al. 2012; Palmer et al. 2014; van Steensel 2012), which involved greater average daily travel distances than females. However, the rural populations differed in that the Klaaskinderkerke males also worked as fishermen. Females often worked closer to the house, milking cows, churning butter, making cheese, pre- paring meals, sewing and washing clothing, and tending to other household chores and children (Falger et al. 2012; van Cruyningen 2005; van Nederveen Meerkerk 2015; van Poppel et al. 2009). While female work often focused on domestic activities, it was com- mon for women to work in the field when additional hands were required (Lindeboom et al. 2012; Mook 1977). The Klaaskinderkerke and Middenbeemster populations will be considered as "rural" based on these similarities in lifestyle, diet, agricultural technology, and division of labor. The dietary staples of the average person in the Netherlands in the 1800s were bread and potato (Wintle 2000). Sometimes vegetables, eggs, and fish or meat were added to a meal (Wintle 2000). The rural Middenbeemster sample may have had a higher intake of dairy products (milk, cheese, butter) than other Dutch citizens given their focus on cattle farming. Stable carbon and nitrogen isotope analyses have revealed a diet composed of $\mathrm{C} 3$ plants and low-trophiclevel protein sources, without evidence for much fresh- water or marine fish consumption; male and female stable isotope means are statistically indistinguishable (Waters-Rist, unpublished data). The late-medieval period staple diet was similar to that of the post- medieval period: mainly cereals supplemented with meat and some vegetables and fruit. However, research has shown that there are some differences between town and country in the late- medieval period. Based on differences in caries frequency between Klaaskinderkerke and Alkmaar, the urban sample consumed more carbohydrates such as starches and sugar, most likely related to greater market dependence (Schats 2016). Additionally, stable isotope research performed on a sample of the Alkmaar population demonstrated an increased consumption of marine fish (Schats 2016; van Hattum 2014). Even though there might have been small differences in diet between the studied populations, considering that the staple foods were similar, it is unlikely that differences in diet were responsible for the variation observed in bone morphology. Hormonal differences between males and females are known to affect diaphyseal bone modeling. While androgens promote periosteal expansion, estrogens inhibit periosteal expansion in favor of endosteal bone packing (Callewaert et al. 2010; Devlin 2011; Gosman et al. 2011; Seeman 2001). Periosteal bone in- creases structural rigidity to a greater extent than endosteal bone, which is thought to be required in women as a reserve of calcium for pregnancy and lactation (Currey 2002; Drinkwater and Chesnut 1991; Ritchie et al. 1998; Seeman 2001). Thus, energetic and functional influences on bone structure may be superseded by additional factors in women. Little experimental work has been performed to assess sex differences in the response to loading in humans. Ryan et al. (2004) found no significant sex differences in the response of bone mineral density to a 6-month regimen of resistive training in young and old men and women. However, Ryan et al. (2004) only examined fully grown adults who are less susceptible to loading than adolescents. Longitudinal studies of male and female athletes and controls would be required to gain a better insight into long bone sexual dimorphism. Taking into account these considerations, adult behaviors can be inferred from lower limb cross-sectional geometry.

Aims and Hypotheses 
This article examines variation in lower limb robusticity and shape as a proxy for the strenuousness of the mechanical environment of pre-industrial Dutch populations. Variation in lower limb rigidity and shape is compared between populations, and sexual dimorphism in lower limb morphology is used to assess potential differences in the division of labor between samples. Higher levels of terrestrial mobility are associated with more anteroposteriorly strengthened femora (greater Ix/Iy) and with greater CSA, bending and torsional rigidity, and more elliptical tibial cross sections (greater Imax/Imin) (Holt 2003; Macintosh et al. 2014; Ruff 2008; Shaw and Stock 2009b; Stock and Pfeiffer $2001,2004)$. The greatest variation in cross-sectional properties associated with levels of terrestrial mobility is found in the midshaft of the femoral and tibial diaphysis (Davies 2012; Davies and Stock 2014; Stock 2006). Thus, by examining variation between femoral and tibial midshaft cross-sectional size and shape, inferences can be made regarding levels of terrestrial mobility in past populations. Considerable evidence has accumulated for a decline in sexual dimorphism in femoral and tibial midshaft shape and rigidity from foraging societies to sedentary agriculturalists to modern industrial societies (Macintosh et al. 2014; Ruff 1987, 2008; Ruff and Hayes 1983a; Ruff et al. 2015). Broad trends in the reduction of sexual dimorphism with time largely suggest a pattern of decline in male diaphyseal rigidity (Macintosh et al. 2014; Ruff 1987, 2008), while some studies have found no changes in sexual dimorphism, or greater change in females (Bridges 1989; Carlson et al. 2007; Sparacello and Marchi 2008). Studies of modern foragers suggest males tend to have higher levels of physical activity (Panter-Brick 2002). These pat- terns become more complex in modern agricultural societies, where in different populations, either males or females are more active (Katzmarzyk et al. 1994; Leonard and Robertson 1992; Murdock and Provost 1973; Panter-Brick 1996, 2002; PanterBrick and Pol- lard 1999). Thus, sexual division of labor is variable in agricultural and modern populations and is subject to complex cultural and ecological influences (Panter- Brick 2002; PanterBrick and Pollard 1999). Contrary to the popular image of pre-industrial societies, recent work has found little variation in skeletal stress indicators between rural and urban Dutch populations. However, historical sources indicate that there are potential differences between urban and rural populations in the strenuousness of daily physical activities and in the way labor is organized between men and women. Lower limb cross-sectional geometry of two rural and one urban pre-industrial Dutch samples are compared to examine the variation in lower limb loading within and between these groups. While cross-sectional geometry is often utilized to assess large-scale trends in behavior through time, the samples in this study consist of relatively sedentary populations. The relative sedentism of the populations would be expected to reduce the magnitude of variation between groups compared to other studies (Macintosh et al. 2014; Marchi et al. 2011; Ruff et al. 2015). However, the populations in this study are highly similar in terms of genetics, geography, diet, culture, and agricultural technology (de Jong et al. 1998; Drukker and Tassenaar 1997; Falger et al. 2012; Lao et al. 2013; Schats 2016; Trimpe Burger and Huizinga 1964; van Hattum 2014; van Steensel 2012; Wintle 2000). Confounding factors that are found in other studies are expected to have a smaller effect, which may allow cross-sectional geometry to pick up more subtle differences between these relatively sedentary populations. Based on the high physical demands of rural economic activities and greater regular travel distance to markets, both rural males and females are expected to be more mobile than their urban contemporaries, resulting in greater lower limb torsional rigidity, CSA, Ix/Iy, and Imax /Imin . The variety of tasks performed in urban and rural communities suggests that there would have been differences in the division of labor between men and women in these contexts. Differences between male and female activity levels are variable in non-forager societies (PanterBrick and Pollard 1999). Based on the historical data detailed for each sample, more variation is expected in lower limb robusticity and shape between males from different samples. Historical sources discussed above for each population suggest that in rural Dutch populations, men typically worked outdoors and travelled further on a daily basis, whereas women were typically involved in activities in or around the house such as food production and spinning wool and linen (Jewell 2007; Kaptein 2007; van Steensel 2012). In urban Alkmaar, both men and women were often employed in the urban industries, but many women were probably working from home or entered household 
service (Hakvoort et al. 2015; Hoppenbrouwers 2001; Jewell 2007; Kaptein 2007). Thus, rural communities are predicted to display greater levels of sexual dimorphism in lower limb rigidity than the urban sample. The historical literature suggests more overlap in female activities involving lower limb loading between the three populations (Falger et al. 2012; Jewell 2007; van Cruyningen 2005; van Nederveen Meerkerk 2015; van Poppel et al. 2009). Thus, variation in sexual dimorphism between populations would be expected to be largely attributable to differences in male behavior involving lower limb loading.

Materials and Methods

Skeletal samples

The cross-sectional geometry of the femur and tibia from three Dutch populations were examined. Forty- three individuals were examined from the rural village of Middenbeemster (early nineteenth century), 20 individuals from rural Klaaskinderkerke (A.D. 1286-1570), and 16 individuals from the late-medieval city (A.D. 1448-1572) of Alkmaar (Figure 1). Age and sex were estimated using Buikstra and Ubelaker's (1994) and the Workshop of European Anthropologists (1980) standards. The effects of age- related bone loss were limited by primarily including only young and middle adults without indications of pathology in the current samples. The majority of individuals fall within the range of 26-45 years of age (Table 1; Figure 2). No significant differences were found in the distribution of age categories between populations and sexes $\left(X^{2}=3.387, \mathrm{df}=6, \mathrm{p}=0.759\right)$.

Preparation of cross sections and determination of cross-sectional properties

Where available, the left tibia and femur were scanned with a Phillips Brilliance 64 CT scanner at the Academic Medical Centre, Amsterdam. Scans were taken at $1 \mathrm{~mm}$ increments with the scanner set to $120 \mathrm{Kv}$, with a $250 \mathrm{~mm}$ wide field of view. A complete 3D digital reconstruction of the bones was generated in Avizo 6.3 in order to determine the location of the midshaft. Diaphyseal cross sections were obtained from the 3D CT images at the femoral and tibial midshaft and saved in DICOM format. These cross- sectional locations were chosen based on standard use in cross-sectional geometry. Reference axes for the femur and the tibia conform to those used by Ruff (2002). The DICOM images of the femoral and tibial cross sections were imported into ImageJ (https://imagej.nih.gov/ij/). Standard cross-sectional proper- ties were calculated with the BoneJ plug-in for ImageJ (Doube 2010). CSA determines a bone's resistance to pure compression. However, a bone is very rarely subjected to pure compression or tension, and a bone's resistance to bending and torsional forces is there- fore mechanically more relevant (Ruff 2008). Bending and torsional rigidity are quantified using the polar second moment of area $(\mathrm{J})$. The distribution of bone throughout cross sections is determined as a ratio of perpendicular cross-sectional planes (Imax/Imin and Ix/Iy ) (Ruff 2008; Ruff and Hayes 1983b). The Ix/Iy ratio is used to quantify diaphyseal shape and anteroposterior/ mediolateral bending rigidity (Ruff 2008). These "shape" indices provide information on how the bone is distributed in the cross section. They allow for a simple assessment of the planes in which a bone is strengthened (Ix/Iy) and whether the bone is relatively circular or strengthened elliptically in an un- specified plane (Imax/Imin). An Ix/Iy value that is higher than 1.0 indicates that a cross section is more robust in the anteroposterior plane at the midshaft, while a value lower than 1.0 indicates that the midshaft is more mediolaterally strengthened. A larger Imax/Imin ratio indicates a more elliptically shaped midshaft. The degree of sexual dimorphism was calculated within each sample. In a review of methods of quantifying levels of sexual dimorphism, Smith (1999) demonstrated that a ratio of male/female mean sufficiently represents sexual dimorphism. The ratio of male mean/female mean was used here and is interpreted in terms of the male mean as a percentage of the female mean. Cross-sectional properties were compared between males and females using independent t-tests. Variation between populations was assessed using one- way ANOVA. Subsequent pairwise comparisons were performed using a Hochberg post hoc test, or a Games-Howell GT2 post hoc test when Levene's test for equality of variance failed. The variability of cross-sectional properties within 
each sample was calculated using the coefficient of variation. Significance of differences in variation between samples were assessed using F-tests following the method described by Lewontin (1966). $\alpha$ was set at 0.05 for all statistical tests.

\section{Size standardization}

Body size inherently influences the loads that are placed upon the limb bones, and thus it needs to be corrected for (Ruff 2008). Body mass was calculated as the average of three equations using the femoral head diameter (provided in Grine et al. 1995; McHenry 1992; Ruff et al. 1991). Pomeroy and Stock (2012) argue that, unless a population is especially large or small, the most accurate way of estimating body mass is to take the average of these three equations. As the cur- rent sample is not especially large or small, the method proposed by Pomeroy and Stock (2012) is applied. The CSA of the femur and tibia was standardized by dividing by body mass. Polar second moment of area relates to the average bending moment when raised to the power of 0.73 (Ruff 1995; Ruff et al. 1993). To standardize for body size, $\mathrm{J}^{0.73}$ is divided by the product of body mass and bone length (Ruff 2000).

\section{Results}

Summary statistics of cross-sectional properties of the femur and tibia are presented in Table 2 and Figure 3. The results of the pairwise post hoc comparisons of the one-way ANOVA between the three populations in both sexes are presented in Table 3. All cross-sectional properties discussed in the following sections are body mass standardized unless specified otherwise. No significant differences are found in the cross-sectional properties of the femur between either sex of any sample. The rural Middenbeemster males do have significantly greater tibial Imax/Imin compared to both other samples ( $\mathrm{df}=2,37, \mathrm{~F}=6.626, \mathrm{p}=0.003$ ), indicating that they have significantly more elliptically shaped tibiae. The sexual dimorphism index and results of t-tests between the males and females within the three samples are presented in Table 4. In the rural Klaaskinderkerke sample the males have significantly greater CSA and $\mathrm{J}$ compared to females in the femur. The males also possess significantly greater CSA and $\mathrm{J}$ in the tibia. This indicates that the rural Klaaskinderkerke males have significantly more robust lower limbs than the females. No significant sexual dimorphism was found in femoral rigidity in the rural Middenbeemster sample. However, males do possess significantly more elliptically shaped tibiae, with significantly greater CSA, Imax /Imin, and J. These variables suggest that the Middenbeemster males have significantly more robust tibiae compared to the females. No significant sexual dimorphism was found in the urban Alkmaar sample in either the femur or the tibia. Coefficients of variation are presented in Table 5 and show differences in the levels of variation between samples. In the femur, the urban Alkmaar males are significantly less variable then the urban Alkmaar females $(\mathrm{p}=0.007)$, rural Klaaskinderkerke females $(\mathrm{p}=0.021)$, and the rural Middenbeemster males $(\mathrm{p}=0.008)$. In the tibia, the urban Alkmaar females show significantly greater variation in CSA than the rural Klaaskinderkerke males $(\mathrm{p}=0.023)$ and the rural Middenbeemster males $(\mathrm{p}=0.005)$ and females $(\mathrm{p}=0.046)$. They also show greater variability in $\mathrm{J}$ compared to the rural Klaaskinderkerke females $(\mathrm{p}=0.046)$ and the rural Middenbeemster males $(\mathrm{p}=0.021)$. The urban Alkmaar males show significantly greater variation than the rural Klaaskinderkerke $(p=0.028)$ and Middenbeemster males $(\mathrm{p}=0.008)$.

\section{Discussion}

This article investigated whether there were differences in habitual activity levels and sexual division of labor between rural and urban pre-industrial Dutch communities. No significant differences between any of the samples were found in the femur. The rural Middenbeemster males do have significantly more elliptically shaped tibiae compared to the urban Alkmaar and the rural Klaaskinderkerke males. Past work suggest that higher levels of terrestrial mobility result in more 
elliptically shaped tibiae (Ruff 2008; Shaw and Stock 2009b). This finding is compatible with higher levels of terrestrial mobility in the rural Middenbeemster males. However, an alternative interpretation is that the males from the other samples were performing a greater variety of activities involving loading from more variable directions. In case of the rural Klaaskinderkerke males, fishing and the excavation of peat are activities that would involve substantial lower limb loading in varying directions. This study would have benefited from including the fibula in the analysis of the lower limb. Recent work has shown that including fibular shape and robusticity provides more information about mobility than the tibia alone (Auerbach et al. 2017; Hagihara and Nara 2016; Marchi and Shaw 2011; Sparacello et al. 2014). The urban Alkmaar sample showed substantially greater variation in cross-sectional properties compared to both rural samples (Table 5). This potentially reflects the greater variation in the activities performed in urban Alkmaar as indicated by historical documents (Kaptein 2007). No significant sexual di- morphism was found in the urban Alkmaar sample. However, significant sexual dimorphism was found in both rural samples. In the femur, the Klaaskinderkerke males have significantly greater CSA and J compared to the females. In both rural Klaaskinderkerke and Middenbeemster the males possessed significantly greater tibial CSA and J compared to the females. These results indicate that males in both rural samples were experiencing significantly greater lower limb loadings compared to the females, while no significant sex differences in loading were present in the urban Alkmaar sample. This indicates the performance of tasks requiring greater levels of limb loading, and possibly greater mobility for both rural male samples. The observation that more significant variation within and between samples is found in the tibiae is consistent with findings in the literature, which suggests that the tibia is more sensitive to mechanical loading than the femur (Davies 2012; Davies and Stock 2014; Macintosh et al. 2014; Stock 2006). Stock (2006) has argued that elements show greater mass optimization between tissue economy and safety factors because they need to be strong enough to prevent fracturing while being as light as possible to reduce the energy required for movement. Stock (2006) argued that proximal elements such as the femora can maintain a greater amount of variation that is not directly related to the functional constraints of the bone. Tibial cross-sectional size and shape is subject to less functional constraint from body size and shape than the femur (Davies 2012). Tibial robusticity and shape are therefore regarded as more reliable indicators of habitual activity than femoral midshaft robusticity and shape in the generally sedentary context of the samples used in this article. Our results show significant differences in lower limb cross-sectional properties between sedentary populations. Striking differences in femoral rigidity have been found between modern athletes and non-athletic control groups, with the most robust femora found in athletes who load their bones irregularly (Niinimäki et al. 2017). Femoral Ix/Iy shows a general reduction over time from the Palaeolithic to modern industrial populations (Ruff 2008). In archaeological work looking at temporal trends in a generally sedentary set- ting, Macintosh et al. (2014) found that the femur does not change in robusticity over time, while only a slight reduction in Ix/Iy is found. However, Macintosh et al. (2014) found a significant reduction in sexual dimorphism through a decline in tibial CSA, J, and Imax /Imin in males, while females reduce in Imax /Imin but not robusticity. These findings turn up throughout the literature, suggesting that the tibia may be more sensitive to more subtle differences in mechanical loading in a general sedentary setting (Davies and Stock 2014; Macintosh et al. 2014; Marchi et al. 2011; Sparacello and Marchi 2008; Stock 2006). Another reason the tibia may be more reliable is that it is less affected by variation in bi-iliac breadth. Pearson et al. (2014) find a small but significant effect of bi-iliac breadth on femoral midshaft cross-sectional properties but not in the tibia. Pearson et al. (2014) propose that the discrepancy between signals from the tibia and femur may result in small part from the effects of body breadth, but they propose additionally that this may be caused by the age at which activities are performed, sensitivity to different loadings, loading from walking versus running, or the fact that the fibula is often ignored as an integral part of the tibia. The substantial variety of tasks generally attributed to Dutch women in the past, including agricultural work, crafts, textile production, and processing of food, likely produced lower levels of lower limb loading compared to the males. Due to the paucity of knowledge regarding sex differences in response to 
mechanical loading, care should be taken when making functional inferences from sexual dimorphism in long bone size and robusticity. However, the observed sexual dimorphism in rural versus urban samples matches predictions based on historical data. We thus interpret the significant differences in tibial robusticity as resulting from greater lower limb loading in males compared to females in rural samples. We have attempted to control for confounding variables as well as possible. Given the above considerations, the most plausible explanation for the significant variation between samples is variation in habitual activity. No significant differences were found between populations in lower limb robusticity, suggesting that overall levels of physical activity did not vary greatly between samples but the more elliptically shaped tibiae in the rural Middenbeemster males suggest they may have been more mobile. How- ever, the results do indicate that urban and rural communities practiced a different sexual division of labor. In rural communities, males experienced greater lower limb loading relative to females, as evidenced by greater male lower limb robusticity in both rural populations and by more elliptically shaped tibiae in the Middenbeemster males. Unfortunately, crosssectional geometry cannot distinguish between the potential frequency or magnitude of loading underlying these results. The significantly greater variation in lower limb robusticity in the urban Alkmaar sample is interpreted as the result of a greater variety of economic activities in the city. The lack of significant differences in lower limb robusticity between urban and rural populations suggests relatively similar levels of physical activity in town and country. Schats (2016) found few differences in nonspecific stress indicators such as growth stunting, enamel hypoplasia, and cribra orbitalia/porotic hyperostosis between medieval Dutch rural and urban populations. This study complements the finding that no large differences are found in general levels of physical activity in these three populations but that the urban and rural populations did practice a different sexual division of labor with males experiencing relatively greater lower limb loading than females in the rural populations. Only small samples were available for the Klaaskinderkerke and Alkmaar populations, resulting in relatively low statistical power. Sexual dimorphism was predicted to be absent or lowest in the Alkmaar. With our small sample size, subtle sexual dimorphism is unlikely to be detected. It was predicted that the rural populations should have more robust lower limbs compared to the urban Alkmaar. Middenbeemster males had more elliptical tibiae, suggesting they may have been more mobile than the other populations, but no differences in lower limb rigidity were found. With larger sample sizes, subtler inter-population differences may emerge. However, the significant differences that were observed are all consistent with the predictions based on historical sources. Another issue is the low number of populations examined in this study. The analysis of additional Dutch populations is currently under way. Future work should also consider examining variation in upper limb crosssectional properties. Preliminary work on the cross-sectional geometry of the upper limb in the rural Middenbeemster sample indicates sexual dimorphism in upper limb use (Saers 2012). This is consistent with previously published work on entheseal changes and osteoarthritis in this population, which found that different types of manual activities were performed by males and females (Palmer et al. 2014).

\section{Conclusions}

Cross-sectional rigidity of the femur and tibia did not significantly differ between populations, although the more elliptically shaped tibiae in the rural Middenbeemster males suggest they may have been more mobile relative to the other males. However, significant sexual dimorphism was found in lower limb diaphyseal rigidity in both rural populations, while sexual dimorphism was absent in the urban Alkmaar population. This indicates that the rural populations most likely had a sexual division of labor in which the males performed activities involving greater lower limb loading than the females. However, this does not mean that a sexual division of labor was absent in the urban Alkmaar population. Instead, this finding indicates that there were no significant sex differences in the levels of lower limb loading in the urban Alkmaar population. Significantly greater variation in lower limb cross- sectional properties was found for both males and females in the urban Alkmaar population 
relative to the rural populations. These results conform to predictions based on the historical literature of greater mobility in rural males compared to females, and a greater variety of tasks performed in urban environments. These findings demonstrate the potential of using cross-sectional geometry to detect behavioral variation between generally sedentary populations when confounding factors are adequately accounted for.

\section{Acknowledgments}

We thank the volunteers of the Historisch Genootschap Beemster for helping clean skeletons and conducting archival research for the Middenbeemster collection. We would like to acknowledge Gemeente Alkmaar and Stichting Cultureel Erfgoed Zeeland for allowing us access to the skeletal collections. We would like to thank Dr. Alison Macintosh for her helpful comments on the manuscript. Finally, we thank co- editors in chief Sabrina Agarwal and Brenda Baker, an associate editor, and three anonymous reviewers whose efforts greatly improved this manuscript. 


\section{References Cited}

Alders, G. 2009. Programma van eisen herinrichting Paardenmarkt 10PAA. Stichting Cultureel Erfgoed Noord-Holland, Alkmaar

Auerbach, Benjamin M., Alice F. Gooding, Colin N. Shaw, and Adam D. Sylvester. $2017 . \quad$ The relative position of the human fibula to the tibia influences cross-sectional properties of the tibia. American Journal of Physical Anthropology 163:148157.DOI: $\quad$ 10.1002/ajpa.23196.

Bennema, Floris P., and Adriaan D. Rijnsdorp. 2015. Fish abundance, fisheries, fish trade and consumption in sixteenth-century Netherlands as described by Adriaen Coenen. Fisheries Research 161:384<n>399. DOI: 10.1016/j.fishres.2014.09.001.

Bridges, Patricia S. 1989. Changes in activities with the shift to agriculture in the southeastern United States. Current Anthropology 30(3): 385<n>394.

Bruinvis, C. W. 1893. Het Minderbroeders-Klooster te Alkmaar. Bijdragen voor de Geschiedenis van het Bisdom van Haarlem 18:29<n>47.

Budnik, Alicja, and Grazyna Liczbińska. 2006. Urban and rural differences in mortality and causes of death in historical Poland. American Journal of Physical Anthropology 129(2):294<n>304. DOI: 10.1002/ajpa.20288.

Buikstra, Jane E., and Douglas H. Ubelaker. 1994. Standards for data collection from human skeletal remains. Arkansas Archaeological Survey Research Series 44:272. DOI: 10.1002/ajhb.1310070519.

Callewaert, Filip, Mieke Sinnesael, Evelien Gielen, Steven Boonen, and Dirk Vanderschueren. 2010. Skeletal sexual dimorphism: Relative contribution of sex steroids, GH-IGF1, and mechanical loading. Journal of Endocrinology 207(2):127<n>134. DOI: 10.1677/JOE-10-0209.

Carlson, Kristian J., Frederick E. Grine, and Osbjorn M. Pearson. 2007. Robusticity and sexual dimorphism in the postcranium of modern hunter-gatherers from Australia. American Journal of Physical Anthropology 134:9<n>23. DOI: 10.1002/ajpa.

Currey, J. D. 2002. Bones: Structure and Mechanics. Princeton University Press, Princeton.

Davies, Thomas G. 2012. Cross-Sectional Variation in the Human Femur and Tibia: The Influence of Physique and Habitual Mobility on Diaphyseal Morphology. University of Cambridge, Cambridge.

Davies, T. G., and J. T. Stock. 2014. The influence of relative body breadth on the diaphyseal morphology of the human lower limb. American Journal of Human Biology 835:822<n>835. DOI: 10.1002/ajhb.22606.

de Feo, Giovanni, George Antoniou, Hilal Franz Fardin, Fatma El-Gohary, Xiao Yun Zheng, Ieva Reklaityte, David Butler, Stavros Yannopoulos, and Andreas N. Angelakis. 2014. The historical development of sewers worldwide. Sustainability 6(6):3936<n>3974.DOI: 10.3390/su6063936.

de Jong, R., M. E. Smit, G. J. Pielage, and A. J. Haartsen. 1998. Nominatiedossier (nederlandse versie): droogmakerij de Beemster aan de hand waarvan de UNESCO droogmakerij de 
Beemster op 1 december 1999 op de werelderfgoedlijst heeft geplaatst. Netherlands Department for Conservation, Zeist.

Demes, Brigitte. 2007. In vivo bone strain and bone functional adaptation. American Journal of Physical Anthropology 133:717<n>722. DOI: 10.1002/ajpa.

Demes, Brigitte, and Kristian J. Carlson. 2009. Locomotor variation and bending regimes of capuchin limb bones. American Journal of Physical Anthropology 139:558<n>571. DOI: 10.1002/ajpa.21020.

Devlin, Maureen J. 2011. Estrogen, exercise, and the skeleton. Evolutionary Anthropology 20(2):54<n>61. DOI: 10.1002/evan.20299.

Doube, Michael. 2010. BoneJ: Free and extensible bone image analysis in Image J. Bone 47:1076<n>1079. DOI: 10.1016/j.bone.2010.08.023

Drinkwater, B. L., and C. H. Chesnut. 1991. Bone density changes during pregnancy and lactation in active women: A longitudinal study. Bone and Mineral 14(2):153<n>160.

Drukker, J. W., and V. Tassenaar. 1997. Paradoxes of modernization and material well-being in the Netherlands during the nineteenth century. In Health and Welfare during Industrialization, edited by R. H. Steckel and R. Floud. University of Chicago Press, Chicago, pp. $331<\mathrm{n}>378$.

Falger, V. S. E., C. A. Beemsterboer-Kohne, and A. J. Kolker. 2012. Nieuwe kroniek van de Beemster. Canaletto, Alphen aan den Rijn.

Fields, G. 1999. Urbanization and the transition from agrarian to industrial society. Berkeley Planning Journal 13(1): $102<\mathrm{n}>128$.

Garn, S. M. 1970. The Earlier Gain and the Later Loss of Cortical Bone in Nutritional Perspective. Charles C. Thomas, Springfield.

Gosman, James H., Samuel D. Stout, and Clark Spencer Larsen. 2011. Skeletal biology over the life span: A view from the surfaces. American Journal of Physical Anthropology 146(SUPPL. 53):86<n>98. DOI: 10.1002/ajpa.21612.

Greendale, G. A., E. Barrett-Connor, S. Edelstein, S. Ingles, and R. Haile. 1995. Lifetime leisure exercise and osteoporosis. Clinical Journal of Sport Medicine 141(10):951<n>959.

Grine, F. E., W. L. Jungers, P. V. Tobias, and O. M. Pearson. 1995. Fossil Homo femur from Berg Aukas, northern Namibia. American Journal of Physical Anthropology 97(2):151<n>185. DOI: 10.1002/ajpa.1330970207.

Haapasalo, H., P. Kannus, H. Sievanen, M. Pasanen, K. Uusi-Rasi, A. Heinonen, P. Oja, and I. Vuori. 1998. Effect of long-term unilateral activity on bone mineral density of female junior tennis players. Journal of Bone and Minereral Research 13(2):310<n>319. DOI: 10.1359/jbmr.1998.13.2.310.

Haapasalo, H., S. Kontulainen, H. Sievänen, P. Kannus, M. Järvinen, and I. Vuori. 2000. Exerciseinduced bone gain is due to enlargement in bone size without a change in volumetric bone density: A peripheral quantitative computed tomography study of the upper arms of male 
tennis players. Bone 27(3):351<n>357. DOI: 10.1016/S8756-3282(00)00331-8

Hagihara, Yasuo, and Takashi Nara. 2016. Morphological features of the fibula in Jomon huntergatherers from the shell mounds of the Pacific coastal area. American Journal of Physical Anthropology 160(4):708<n>718. DOI: 10.1002/ajpa.23000.

Hakvoort, A., A. Griffioen, R. Schats, and P. Bitter. 2015. Graven en begraven bij de Minderbroeders: Een archeologische opgraving op de Paardenmarkt in Alkmaar. Rapporten over de Alkmaarse Monumenten en Archeologie 22. Gemeente Alkmaar, Alkmaar.

Harrison, G. A., and J. B. Gibson. 1976. Man in Urban Environments. Oxford University Press, Oxford.

Higgins, R. W. 2014. The effects of terrain on long bone robusticity and cross-sectional shape in lower limb bones of bovids, Neandertals, and Upper Paleolithic modern humans. In Reconstructing Mobility: Environmental, Behavioral, and Morphological Determinants, edited by K. J. Carlson and D. Marchi. Springer, New York, pp. $227<\mathrm{n}>252$.

Hohenberg, Paul M. 1995. The Making of Urban Europe, 1000<n>1994. Harvard University Press, Cambridge.

Holt, Brigitte M. 2003. Mobility in Upper Paleolithic and Mesolithic Europe: Evidence from the lower limb. American Journal of Physical Anthropology 122(3):200<n>215. DOI: 10.1002/ajpa.10256.

Hoppenbrouwers, P. C. M. 2001. Town and country in Holland, $1300<\mathrm{n}>1500$. In Town and Country in Europe, $1300<n>1800$, edited by S. R. Epstein. Cambridge University Press, Cambridge, pp. $54<$ n $>79$.

Jewell, H. M. 2007. Women in Late Medieval and Reformation Europe, $1200<n>1550$. Palgrave Macmillan, New York.

Judex, S., T. S. Gross, and R. F. Zernicke. 1997. Strain gradients correlate with sites of exerciseinduced bone-forming surfaces in the adult skeleton. Journal of Bone and Mineral Research 12(10):1737<n>1745. DOI: 10.1359/jbmr.1997.12.10.1737.

Kaptein, H. 2007. Streekcentrum in wording: De economische ontwikkeling van een marktstad. In Geschiedenis van Alkmaar, edited by D. Aten, J. Drewes, J. Kila, and H. de Raad. Waanders Uitgeverij, Zwolle, pp. $91<\mathrm{n}>103$.

Katzmarzyk, P., W. Leonard, M. Crawford, and R. Sukernik. 1994. Resting metabolic rate and daily energy expenditure among two indigenous Siberian populations. American Journal of Human Biology 6(6):719<n>730. DOI: 10.1002/ajhb.1310060606.

Kontulainen, Saija, Harri Sievänen, Pekka Kannus, Matti Pasanen, and Ilkka Vuori. 2003. Effect of long-term impact-loading on mass, size, and estimated strength of humerus and radius of female racquet-sports players: A peripheral quantitative computed tomography study between young and old starters and controls. Journal of Bone and Mineral Research 18(2):352<n>359. DOI: $10.1359 / \mathrm{jbmr} .2003 .18 .2 .352$. 
Kriska, A. M., R. B. Sandler, J. A. Cauley, R. E. LaPorte, D. L. Hom, and G. Pambianco. 1988. The assessment of historical physical activity and its relation to adult bone parameters. American Journal of Epidemiology 127(5):1053<n>1063.

Lao, Oscar, Eveline Altena, Christian Becker, Silke Brauer, Thirsa Kraaijenbrink, Mannis van Oven, Peter Nürnberg, Peter de Knijff, and Manfred Kayser. 2013. Clinal distribution of human genomic diversity across the Netherlands despite archaeological evidence for genetic discontinuities in Dutch population history. Investigative Genetics $4(1): 1<\mathrm{n}>14$. DOI: 10.1186/2041-2223-4-9.

Leenders, K. A. H. W. 1999. Ecologische aspecten van de middeleeuwse zoutwinning in de Delta. Jaarboek voor Ecologische Geschiedenis 1: 43<n>60.

Leenders, K. A. H. W. 2004. De interactie tussen mens en natuur in de strijd om land en water in het zuiden van Holland, $1200<\mathrm{n}>1650$. Holland $3: 143<\mathrm{n}>161$.

Lemmers, S. A. M., R. Schats, M. L. P. Hoogland, and A. L. Waters-Rist. 2013. Fysisch antropologische analyse Middenbeemster. In De Begravingen bij de Keyserkerk te Middenbeemster, edited by A. Hakvoort pp. $35<\mathrm{n}>60$. Hollandia reeks, Amsterdam.

Leonard, William R., and Marcia L. Robertson. 1992. Nutritional requirements and human evolution : A bioenergetics model. American Journal of Human Biology 4:179<n>195. DOI: 10.1002/ajhb.1310040204.

Lewis, Mary E. 2002. Impact of industrialization: Comparative study of child health in four sites from medieval and postmedieval England (A.D. 850<n>1859). American Journal of Physical Anthropology 119(3):211<n>223. DOI: 10.1002/ajpa.10126.

Lewontin, R.C. 1966. On the measurement of relative variability. Systematic Zoology 15:141<n>142. DOI: $10.2307 /$ sysbio/15.2.141.

Lieberman, Daniel E., John D. Polk, and Brigitte Demes. 2004. Predicting long bone loading from cross-sectional geometry. American Journal of Physical Anthropology 123(2):156<n>171. DOI: 10.1002/ajpa.10316.

Lillehammer, Grete. 2010. Archaeology of children. Complutum 21(2):15<n>45.

Lindeboom, M., M. Poplawska, F. Portrait, and G. van den Berg. 2012. Nutrition Early in Life and Longevity. Bonn.

Lucassen, J. 2002. Immigranten in Holland, 1600<n>1800: Een kwantitatieve benadering. Centrum voor Geschiedenis Migranten, Amsterdam.

Macintosh, A. A., R. Pinhasi, and J. T. Stock. 2014. Lower limb skeletal biomechanics track longterm decline in mobility across $\sim 6150$ years of agriculture in central Europe. Journal of Archaeological Science 52:376<n>390. DOI: 10.1016/j.jas.2014.09.001.

Marchi, Damiano. 2008. Relationships between lower limb cross-sectional geometry and mobility: The case of a Neolithic sample from Italy. American Journal of Physical Anthropology 137(2):188<n>200. DOI: 10.1002/ajpa.20855. 
Marchi, Damiano, and Colin N. Shaw. 2011. Variation in fibular robusticity reflects variation in mobility patterns. Journal of Human Evolution 61(5):609<n>616. DOI: 10.1016/j.jhevol.2011.08.005.

Marchi, Damiano, Vitale S. Sparacello, Brigitte M. Holt, and Vincenzo Formicola. 2006. Biomechanical approach to the reconstruction of activity patterns in Neolithic Western Liguria , Italy. American Journal of Physical Anthropology 131:447<n>455. DOI: 10.1002/ajpa.

Marchi, Damiano, Vitale Sparacello, and Colin Shaw. 2011. Mobility and lower limb robusticity of a pastoralist Neolithic population from north-western Italy. In Human Bioarchaeology of the Transition to Agriculture, edited by R. Pinhasi and J. T. Stock. Wiley-Blackwell, Chichester, pp. $317<\mathrm{n}>346$.

McHenry, Henry M. 1992. Body size and proportions in early hominids. American Journal of Physical Anthropology 87:407<n>431.

Mook, Bertha. 1977. The Dutch Family in the 17th and 18th Centuries. University of Ottawa Press, Ottawa.

Murdock, G. P., and C. Provost. 1973. Factors in the division of labor by sex: A cross-cultural analysis. Ethnology 12(2):203<n>225.

Niinimäki, Sirpa, Nathaniel Narra, Laura Härkönen, Shinya Abe, Riku Nikander, Jari Hyttinen, Christopher Knüsel, and Harri Sievänen. 2017. The relationship between loading history and proximal femoral diaphysis cross-sectional geometry. American Journal of Human Biology e22965:1<n>14. DOI: 10.1002/ajhb.22965.

Nikander, Riku, Harri Sievänen, Kirsti Uusi-Rasi, Ari Heinonen, and Pekka Kannus. 2006. Loading modalities and bone structures at nonweight-bearing upper extremity and weight-bearing lower extremity: A pQCT study of adult female athletes. Bone 39(4):886<n>894. DOI: 10.1016/j.bone.2006.04.005.

Palmer, Jessica, Menno Hoogland, and Andrea Waters-Rist. 2014. Activity reconstruction of postmedieval Dutch rural villagers from upper limb osteoarthritis and entheseal changes. International Journal of Osteoarchaeology 92(January):78<n>92. DOI: 10.1002/oa.2397.

Panter-Brick, Catherine. 1996. Seasonal and sex variation in physical activity levels among agropastoralists in Nepal. American Journal of Physical Anthropology 100(1):7<n >21. DOI: 10.1002/(SICI)1096-8644(199605)100:1.

Panter-Brick, Catherine. 2002. Sexual division of labor: Energetic and evolutionary scenarios. American Journal of Human Biology 14(5):627<n>640. DOI: 10.1002/ajhb.10074.

Panter-Brick, Catherine, and Tessa M. Pollard. 1999. Work and hormonal variation in subsistence and industrial contexts. In Hormones, Health, and Behavior: A Socio-Ecological and Lifespan Perspective., edited by Catherine Panter-Brick and Carol M. Worthman. Cambridge University Press, Cambridge, pp. $139<\mathrm{n}>183$.

Pearson, Osbjorn Magnus., and Daniel E. Lieberman. 2004. The aging of Wolff's "law": Ontogeny 
and responses to mechanical loading in cortical bone. American Journal of Physical Anthropology Suppl 39:63<n>99. DOI: 10.1002/ajpa.20155.

Pearson, Osbjorn Magnus, Timothy. R. Petersen, Vitale S. Sparacello, Shamsi. R. Daneshvari, and Frederick E. Grine. 2014. Activity, "body shape," and cross-sectional geometry of the femur and tibia. In Reconstructing Mobility: Environmental, Behavioral, and Morphological Determinants , edited by K. J. Carlson and D. Marchi. Springer, New York, pp. 133-152.

Pitts, Martin, and Rebecca Griffin. 2012. Exploring health and social well-being in Late Roman Britain: An intercemetery approach. American Jounal of Archaeology 116(2):253<n>276. DOI: 10.3764/aja.116.2.0253.

Pomeroy, Emma. 2013. Biomechanical insights into activity and long distance trade in the southcentral Andes (AD 500<n>1450). Journal of Archaeological Science 40(8):3129<n>3140. DOI: $10.1016 /$ j.jas.2013.04.019.

Pomeroy, Emma, and Stock, J.T. 2012. Estimation of stature and body mass from the skeleton among coastal and mid-altitude Andean populations. American Journal of Physical Anthropology 147(2):264<n>279. DOI: 10.1002/ajpa.21644.

Redfern, Rebecca C., Sharon N. Dewitte, John Pearce, Christine Hamlin, and Kirsten Egging Dinwiddy. 2015. Urban-rural differences in Roman Dorset, England: A bioarchaeological perspective on Roman settlements. American Journal of Physical Anthropology 157(1):107<n>120. DOI: 10.1002/ajpa.22693.

Riddle, John M. 2008. A History of the Middle Ages, 300<n>1500. Rowman \& Littlefield, Lanham.

Ritchie, L. D., E. B. Fung, B. P. Halloran, J. R. Turnlund, M. D. Van Loan, C. E. Cann, and J. C. King. 1998. A longitudinal study of calcium homeostasis during human pregnancy and lactation and after resumption of menses. American Journal of Clinical Nutrition 67(4):693<n>701.

Roberts, Charlotte, and Margaret Cox. 2003. Health and Disease in Britain: From Prehistory to the Present Day. Sutton, Gloucester.

Ruff, Christopher. 1987. Sexual dimorphism in human lower limb bone structure: Relationship to subsistence strategy and sexual division of labor. Journal of Human Evolution 16(5):391<n>416. DOI: 10.1016/0047-2484(87)90069-8.

Ruff, Christopher. B. 1995. Biomechanics of the hip and birth in early Homo. American Journal of Physical Anthropology 98(4):527<n>574. DOI: 10.1002/ajpa.1330980412.

Ruff, Christopher. B. 2000. Body size, body shape, and long bone strength in modern humans. Journal of Human Evolution 38(2):269<n>290. DOI: 10.1006/jhev.1999.0322.

Ruff, Christopher B. 2002. Long bone articular and diaphyseal structure in old world monkeys and apes: I. Locomotor effects. American Journal of Physical Anthropology 119(4):305<n>342. DOI: 10.1002/ajpa.10117.

Ruff, Christopher B. 2008. Biomechanical analyses of archaeological human skeletons. In Biological 
Anthropology of the Human Skeleton, edited by S. R. Katzenberg and M. A. Saunders. 2nd ed. Wiley-Blackwell, Chichester, pp. $183<\mathrm{n}>206$.

Ruff, Christopher. B., and Wilson. C. Hayes. 1983a. Cross-sectional geometry of Pecos Pueblo femora and tibiae--a biomechanical investigation: I. Method and general patterns of variation. American Journal of Physical Anthropology 60(3):359<n>381. DOI: 10.1002/ajpa.1330600308.

Ruff, Christopher. B., and Wilson. C. Hayes. 1983b. Cross-sectional geometry of Pecos Pueblo femora and tibiae--a biomechanical investigation: II. Sex, age, side differences. American Journal of Physical Anthropology 60(3):383<n>400. DOI: 10.1002/ajpa.1330600309.

Ruff, Christopher B., Brigitte M. Holt, and Erik Trinkaus. 2006. Who's afraid of the big bad Wolff? "Wolff's Law" and bone functional adaptation. American Journal of Physical Anthropology 129:484<n>498. DOI: 10.1002/ajpa.

Ruff, Christopher B., Brigitte Holt, Markku Niskanen, Vladimir Sladek, Margit Berner, Evan Garofalo, Heather M Garvin, Martin Hora, Juho-antti Junno, Eliska Schuplerova, Rosa Vilkama, and Erin Whittey. 2015. Gradual decline in mobility with the adoption of food production in Europe. Proceedings of the National Academy of Sciences 112(23): $7147<$ n> 7152. DOI: $10.1073 /$ pnas. 1502932112 .

Ruff, Christopher. B., William. W. Scott, and Allie Y. Liu. 1991. Articular and diaphyseal remodeling of the proximal femur with changes in body mass in adults. American Journal of Physical Anthropology 86(3):397<n>413. DOI: 10.1002/ajpa.1330860306.

Ruff, Christopher B., Erik Trinkaus, and Alan Walker. 1993. Postcranial robusticity in Homo: I. Temporal trends and mechanical interpretation. American Journal of Physical Anthropology $91: 21<\mathrm{n}>53$.

Ryan, Alice S., Fred M. Ivey, Diane E. Hurlbut, Gregory F. Martel, Jeffrey T. Lemmer, John D. Sorkin, E. Jeffrey Metter, Jerome L. Fleg, and Ben F. Hurley. 2004. Regional bone mineral density after resistive training in young and older men and women. Scandinavian Journal of Medicine and Science in Sports 14:16<n>23. DOI: 10.1046/j.1600-0838.2003.00328.x.

Saers, Jaap. 2012. Sexual Division of Labour in Rural 17th to 19th Century Holland: A Study of Limb Bone Cross-Sectional Geometry. Leiden University, Leiden.

Schats, Rachel. 2016. Life in Transition: An Osteoarchaeological Perspective of the Consequences of Medieval Socioeconomic Developments in Holland and Zeeland (AD 1000<n>1600). Leiden University, Leiden.

Seeman, Ego. 2001. Clinical review 137: Sexual dimorphism in skeletal size, density, and strength. Journal of Clinical Endocrinology and Metabolism 86(10):4576<n $>4584$. DOI: $10.1210 /$ jc. 86.10 .4576 .

Shaw, Colin N., and Jay. T. Stock. 2009a. Habitual throwing and swimming correspond with upper limb diaphyseal strength and shape in modern human athletes. American Journal of Physical 
Anthropology 140(1):160<n>172. DOI: 10.1002/ajpa.21063.

Shaw, Colin N., and Jay T. Stock. 2009b. Intensity, repetitiveness, and directionality of habitual adolescent mobility patterns influence the tibial diaphysis morphology of athletes. American Journal of Physical Anthropology 140(1):149<n>159. DOI: 10.1002/ajpa.21064.

Shaw, Colin N., and Jay T. Stock. 2013. Extreme mobility in the Late Pleistocene? Comparing limb biomechanics among fossil Homo, varsity athletes and Holocene foragers. Journal of Human Evolution 64(4):242<n>249. DOI: 10.1016/j.jhevol.2013.01.004.

Smith, Richard J. 1999. Statistics of sexual size dimorphism. Journal of Human Evolution 36(4):423<n>458. DOI: 10.1006/jhev.1998.0281.

Sparacello, Vitale, and Damiano Marchi. 2008. Mobility and subsistence economy: A diachronic comparison between two groups settled in the same geographical area (Liguria, Italy). American Journal of Physical Anthropology 136(4):485<n>495. DOI: 10.1002/ajpa.20832.

Sparacello, Vitale S., Damiano Marchi, and Colin N. Shaw. 2014. The importance of considering fibular robusticity when inferring the mobility patterns of past populations. In Reconstructing Mobility: Environmental, Behavioural and Morphological Determinants, edited by Kristian J. Carlson and Damiano Marchi. Springer, New York, pp. $91<\mathrm{n}>111$.

Sparacello, Vitale S., Osbjorn Magnus Pearson, A. Coppa, and Damiano Marchi. 2011. Changes in skeletal robusticity in an iron age agropastoral group: The Samnites from the Alfedena necropolis (Abruzzo, Central Italy). American Journal of Physical Anthropology 144(1):119<n>130. DOI: 10.1002/ajpa.21377.

Stock, Jay. T. 2006. Hunter-gatherer postcranial robusticity relative to patterns of mobility, climatic adaptation, and selection for tissue economy. American Journal of Physical Anthropology 131(2):194<n>204. DOI: 10.1002/ajpa.20398.

Stock, Jay., and Susan. K. Pfeiffer. 2001. Linking structural variability in long bone diaphyses to habitual behaviors: foragers from the southern African Later Stone Age and the Andaman Islands. American Journal of Physical Anthropology 115(4):337<n>348. DOI: 10.1002/ajpa.1090.

Stock, Jay. T., and Susan. K. Pfeiffer. 2004. Long bone robusticity and subsistence behaviour among Later Stone Age foragers of the forest and fynbos biomes of South Africa. Journal of Archaeological Science 31(7):999<n>1013. DOI: 10.1016/j.jas.2003.12.012.

Sugiyama, Toshihiro, Joanna S. Price, and Lance E. Lanyon. 2010. Functional adaptation to mechanical loading in both cortical and cancellous bone is controlled locally and is confined to the loaded bones. Bone 46(2):314<n>321. DOI: 10.1016/j.bone.2009.08.054.

Teegarden, D., W. R. Proulx, M. Kern, D. Sedlock, C. M. Weaver, C. C. Johnston, and R. M. Lyle. 1996. Previous physical activity relates to bone mineral measures in young women. Medicine and Science in Sports and Exercise 28(1):105<n>113.

Trimpe Burger, J. A., and J. Huizinga. 1964. Kerk, begraafplaats en bevolking van het in de 16de 
eeuw verlaten dorp Klaaskinderkerke op Schouwen. Proceedings of the State Service for Archaeological Investigation in The Netherlands 12(13):559<n>570.

Trinkaus, Erik., Steven. E. Churchill, and Christopher. B. Ruff. 1994. Postcranial robusticity in Homo: II. Humeral bilateral asymmetry and bone plasticity. American Journal of Physical Anthropology 93(1):1<n>34. DOI: 10.1002/ajpa.1330930102.

Unger, R. W. 1978. The Netherlands herring fishery in the Late Middle Ages: The false legend of Willem Beukels of Biervliet. Viator 9(1):335<n>356.

van Cruyningen, P. 2005. Vrouwenarbeid in de Zeeuwe landbouw in de achttiende eeuw. Tijdschrift voor Sociale en Economische Geschiedenis 2:43<n>59.

van Hattum, I. 2014. "What's on the Menu?" Diet in Medieval Holland: A Stable Carbon and Nitrogen Isotope Analysis of Bone "Collagen" from Early Medieval Blokhuizen and Late Medieval Alkmaar. Leiden University, Leiden.

van Nederveen Meerkerk, E. 2015. Vergelijkingen en verbindingen: De arbeidsdeelname van vrouwen in Nederland en Nederlands-Indië, 1813<n>1940. BMGN—Low Countries Historical Review 130:13<n>43. http://doi.org/10.18352/bmgn-lchr.10039

van Poppel, F. W. A., H. P. van Dalen, and E. Walhout. 2009. Diffusion of a social norm: Tracing the emergence of the housewife in the Netherlands, 1812<n>1922. Economic History Review $62: 99<\mathrm{n}>127$.

van Steensel, A. 2012. De economie van het platteland. In Geschiedenis van Zeeland, edited by P. Brusse and P. A. Hendrikx. WBooks, Zwolle, pp. $265<\mathrm{n}>276$.

Vikatou, I., M. L. P. Hoogland, and A. L. Waters-Rist. 2017. Osteochondritis Dissecans of skeletal elements of the foot in a 19th century rural farming community from The Netherlands. International Journal of Paleopathology.

Waldron, Tony. 1989. The effects of urbanisation on human health: The evidence from skeletal remains. In Diet and Crafts in Towns. The Evidence of Animal Remains from the Roman to the Post-Medieval Periods, edited by D. Serjeantson and T. Waldron. BAR series, Oxford, pp. $55<\mathrm{n}>74$.

Wallace, Ian J., Brigitte Demes, Carrie Mongle, Osbjorn M. Pearson, John D. Polk, and Daniel E. Lieberman. 2014. Exercise-induced bone formation is poorly linked to local strain magnitude in the sheep tibia. PloS ONE 9(6):e99108. DOI: 10.1371/journal.pone.0099108.

Wallace, Ian J., Steven M. Tommasini, Stefan Judex, Theodore Garland, and Brigitte Demes. 2012. Genetic variations and physical activity as determinants of limb bone morphology: An experimental approach using a mouse model. American Journal of Physical Anthropology 148(1):24<n>35. DOI: 10.1002/ajpa.22028.

Wintle, M. 2000. An Economic and Social History of the Netherlands, 1800<n>1920: Demographic, Economic and Social Transition. Cambridge University Press, Cambridge.

Workshop of European Anthropologists. 1980. Recommendations for age and sex diagnosis of 
skeletons. Journal of Human Evolution 9:517<n>549.

Figures

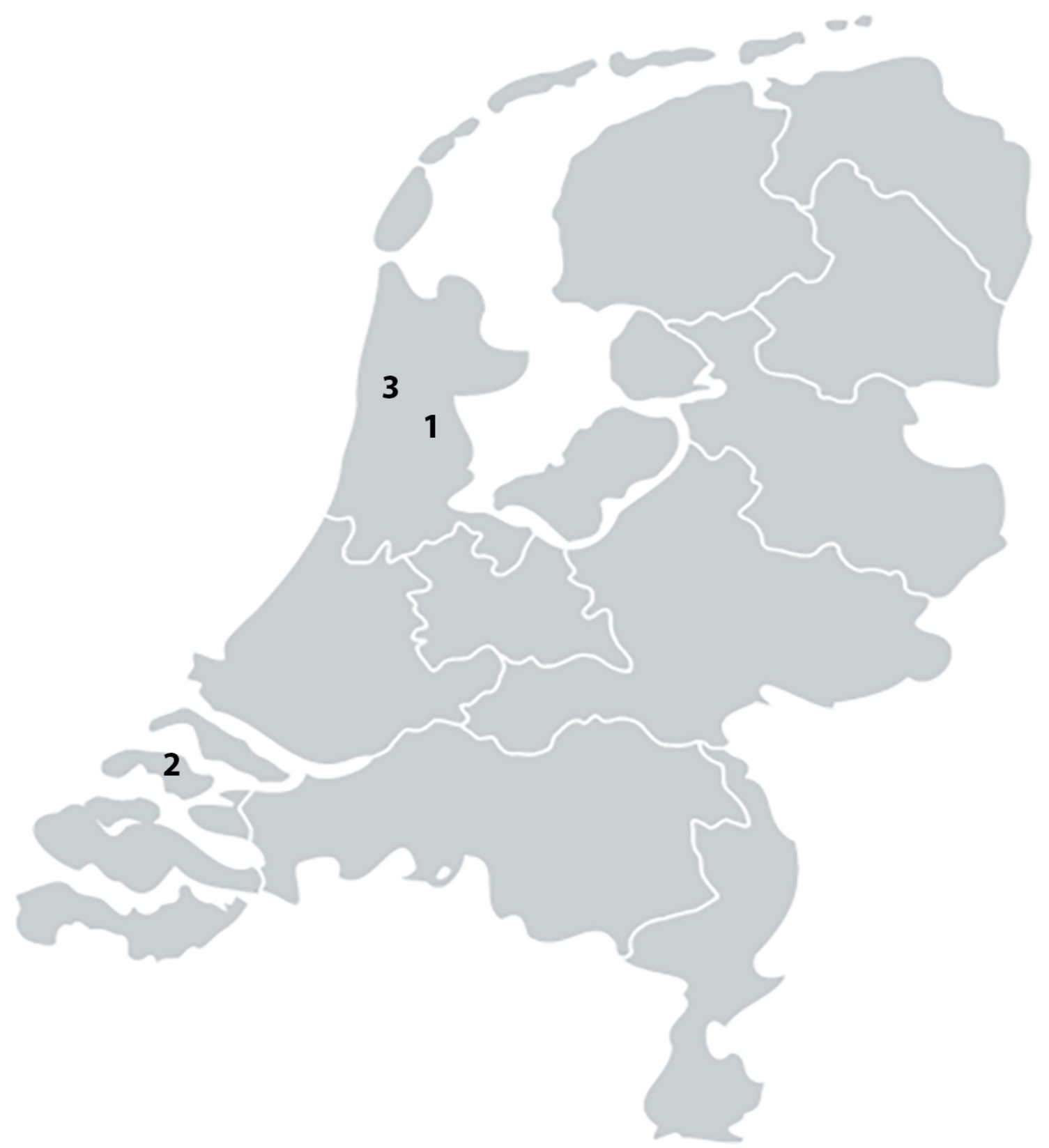

Figure 1. Map of the Netherlands with locations of the three sites: Middenbeemster (1), Klaaskinderkerke (2), Alkmaar (3). 


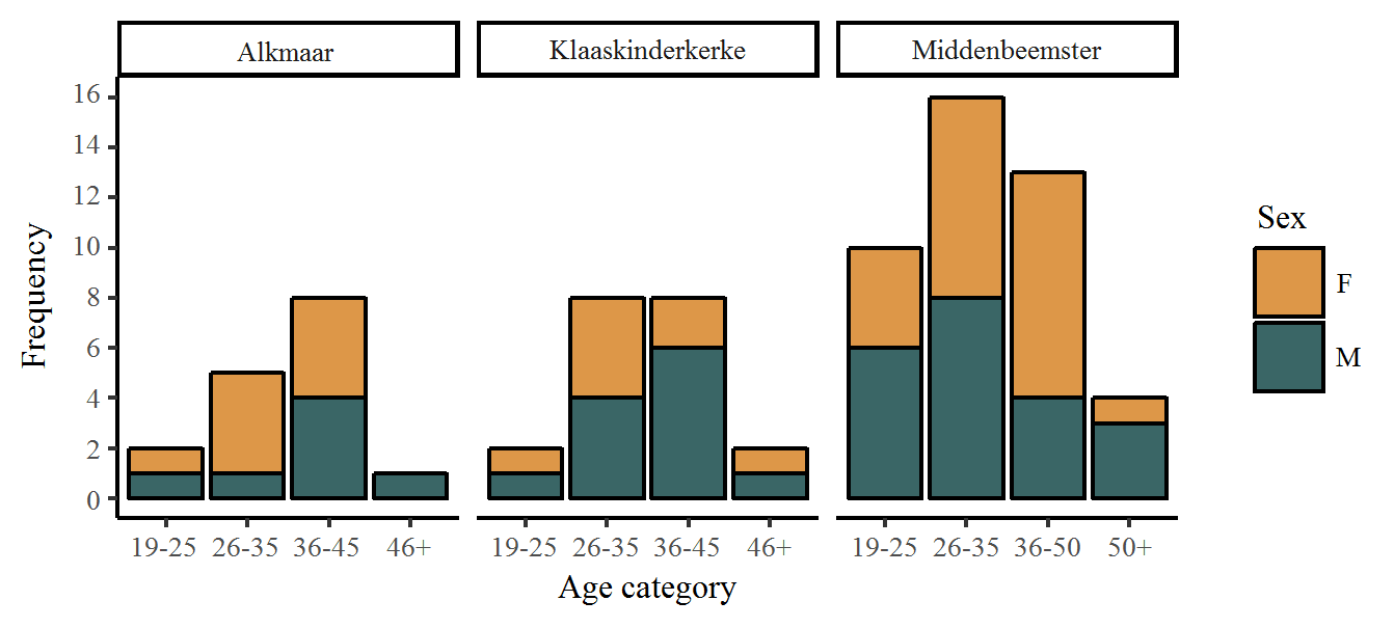

Figure 2. Frequency plot of age categories for each sex and population.
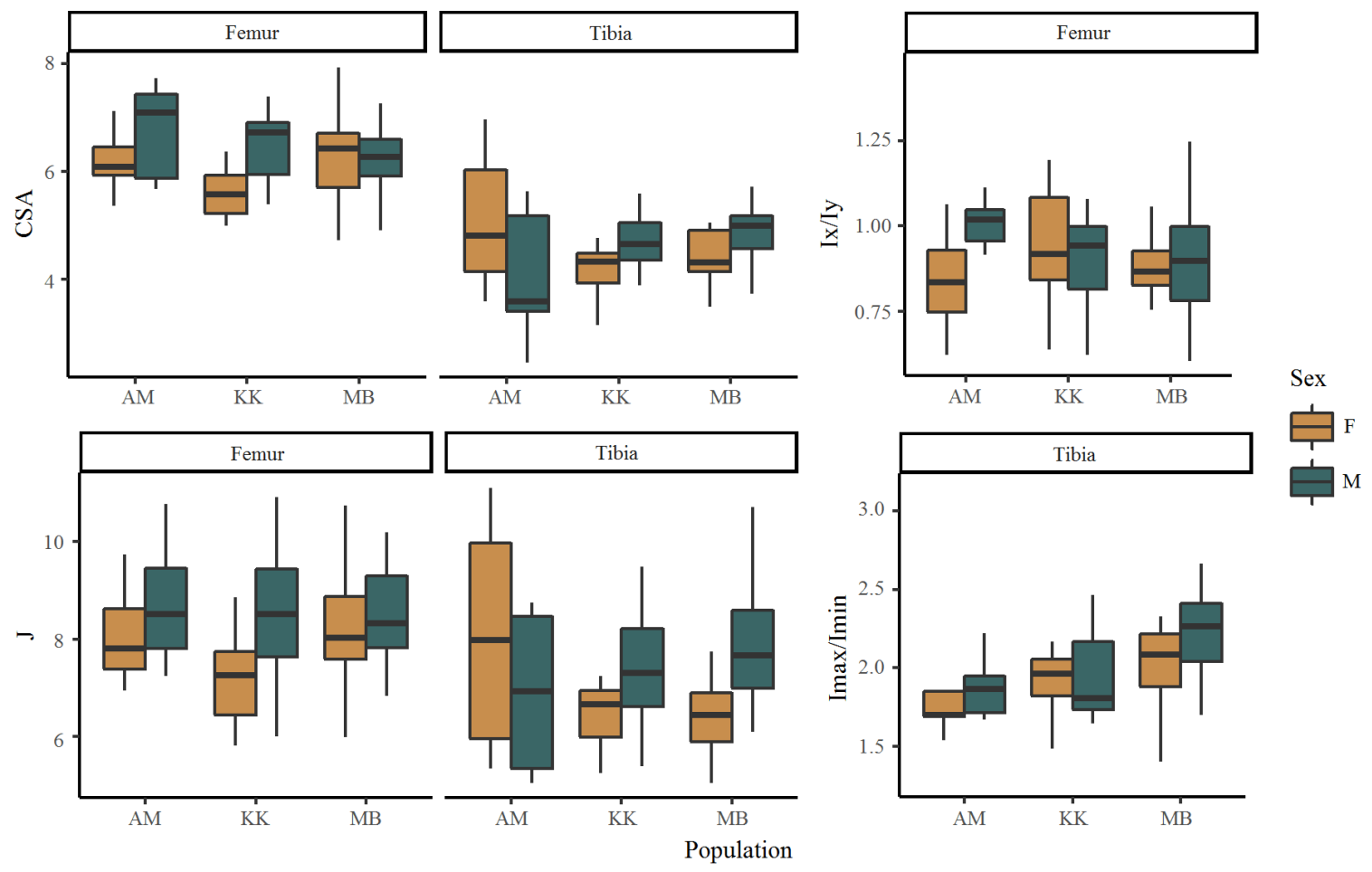

Figure 3. Box plots of size standardized cross-sectional properties in Middenbeemster (MB), Alkmaar $(A M)$, and Klaaskinderkerke $(K K) . C S A=$ cross-sectional area, $I_{x}=$ anteroposterior bending rigidity, $I_{y}=$ mediolateral bending rigidity, $I_{\min }=$ minimum bending rigidity, $I_{\max }=$ maximum bending rigidity, $J=$ torsional rigidity. 
Tables

Table 1. Distribution of Age Groups in the Samples.

\begin{tabular}{lrccccc} 
Age Category & \multicolumn{2}{c}{ Alkmaar } & \multicolumn{2}{c}{ Klaaskinderkerke } & \multicolumn{2}{c}{ Middenbeemster } \\
\cline { 2 - 8 } & M (7) & F (9) & M (12) & F (8) & M (21) & F (22) \\
$\mathbf{1 8}<\mathbf{n}>\mathbf{2 5}$ & 0.14 & 0.11 & 0.08 & 0.13 & 0.29 & 0.18 \\
$\mathbf{2 6}<\mathbf{n}>\mathbf{3 5}$ & 0.14 & 0.44 & 0.33 & 0.50 & 0.38 & 0.36 \\
$\mathbf{3 6}<\mathbf{n}>\mathbf{4 5}$ & 0.57 & 0.44 & 0.50 & 0.25 & 0.19 & 0.41 \\
$\mathbf{4 6 +}$ & 0.14 & 0.00 & 0.08 & 0.13 & 0.14 & 0.05
\end{tabular}

Table 2. Summary Statistics of Cross-sectional Properties. CSA = cross-sectional area, $I_{x}=$ anteroposterior bending rigidity, $I_{y}=$ mediolateral bending rigidity, $I_{\min }=$ minimum bending rigidity, $I_{\max }=$ maximum bending rigidity, $J=$ torsional rigidity. CSA is standardized by dividing by body mass, $J$ was standardized by dividing $J^{0.73}$ by the product of estimated body mass multiplied by bone length.

\begin{tabular}{|c|c|c|c|c|c|c|c|c|}
\hline \multirow[t]{3}{*}{ Bone } & \multirow[t]{3}{*}{ Sex } & \multirow[t]{3}{*}{ Population } & \multirow[t]{3}{*}{$N$} & $\begin{array}{l}\text { Body } \\
\text { Mass }\end{array}$ & $\mathbf{I}_{\mathbf{x}} / \mathbf{I}_{\mathbf{y}}$ & $\begin{array}{c}\mathbf{I}_{\max } / \\
\mathbf{I}_{\min }\end{array}$ & CSA & $\mathbf{J}$ \\
\hline & & & & Mean & Mean & Mean & Mean & Mean \\
\hline & & & & SD & SD & SD & SD & SD \\
\hline \multirow[t]{12}{*}{ Femur } & \multirow[t]{6}{*}{ Male } & \multirow[t]{2}{*}{ Klaaskinderkerke } & \multirow[t]{2}{*}{12} & 74.11 & 0.91 & 1.27 & 6.47 & 8.49 \\
\hline & & & & 5.38 & 0.13 & 0.22 & 0.67 & 1.42 \\
\hline & & \multirow{2}{*}{ Middenbeemster } & \multirow[t]{2}{*}{21} & 76.30 & 0.94 & 1.30 & 6.19 & 8.49 \\
\hline & & & & 5.60 & 0.21 & 0.14 & 0.55 & 0.96 \\
\hline & & \multirow[t]{2}{*}{ Alkmaar } & \multirow[t]{2}{*}{7} & 72.81 & 1.01 & 1.23 & 6.73 & 8.73 \\
\hline & & & & 7.25 & 0.07 & 0.15 & 0.89 & 1.28 \\
\hline & \multirow[t]{6}{*}{ Female } & \multirow[t]{2}{*}{ Klaaskinderkerke } & \multirow[t]{2}{*}{8} & 62.97 & 0.95 & 1.28 & 5.60 & 7.22 \\
\hline & & & & 4.94 & 0.19 & 0.26 & 0.51 & 1.02 \\
\hline & & \multirow{2}{*}{ Middenbeemster } & \multirow[t]{2}{*}{22} & 61.11 & 0.89 & 1.29 & 6.24 & 8.26 \\
\hline & & & & 6.49 & 0.13 & 0.16 & 0.77 & 1.34 \\
\hline & & \multirow[t]{2}{*}{ Alkmaar } & \multirow[t]{2}{*}{9} & 63.01 & 0.87 & 1.34 & 6.16 & 8.04 \\
\hline & & & & 4.69 & 0.21 & 0.22 & 0.59 & 0.89 \\
\hline \multirow{12}{*}{ Tibia } & \multirow{6}{*}{ Male } & \multirow{2}{*}{ Klaaskinderkerke } & \multirow[t]{2}{*}{12} & 74.11 & 1.41 & 1.93 & 4.67 & 7.44 \\
\hline & & & & 5.38 & 0.28 & 0.27 & 0.54 & 1.28 \\
\hline & & \multirow[t]{2}{*}{ Middenbeemster } & \multirow[t]{2}{*}{21} & 76.30 & 1.39 & 2.26 & 4.88 & 7.82 \\
\hline & & & & 5.60 & 0.32 & 0.34 & 0.55 & 1.09 \\
\hline & & \multirow[t]{2}{*}{ Alkmaar } & \multirow[t]{2}{*}{7} & 72.81 & 1.24 & 1.87 & 4.12 & 6.91 \\
\hline & & & & 7.25 & 0.28 & 0.20 & 1.20 & 1.72 \\
\hline & \multirow{6}{*}{ Female } & \multirow{2}{*}{ Klaaskinderkerke } & \multirow[t]{2}{*}{8} & 62.97 & 1.47 & 1.92 & 4.15 & 6.42 \\
\hline & & & & 4.94 & 0.22 & 0.22 & 0.53 & 0.75 \\
\hline & & \multirow{2}{*}{ Middenbeemster } & 21 & 61.11 & 1.39 & 2.01 & 4.49 & 6.54 \\
\hline & & & & 6.49 & 0.33 & 0.28 & 0.64 & 1.11 \\
\hline & & Alkmaar & 9 & 63.01 & 1.38 & 1.78 & 5.11 & 8.03 \\
\hline & & & & 4.69 & 0.22 & 0.32 & 1.26 & 2.11 \\
\hline
\end{tabular}


Table 3. One-way ANOVA Pairwise Post Hoc Comparisons between Three Populations. Hochberg post hoc analysis was used when Levene's test was met. ${ }^{a}$ indicates Levene's test failed in which case Games-Howell GT2 was used. Significant results are in bold. $K=$ Klaaskinderkerke (rural); $M=$ Middenbeemster (rural); A = Alkmaar (urban). CSA is standardized by dividing by body mass, J was standardized by dividing $J^{0.73}$ by the product of estimated body mass multiplied by bone length.

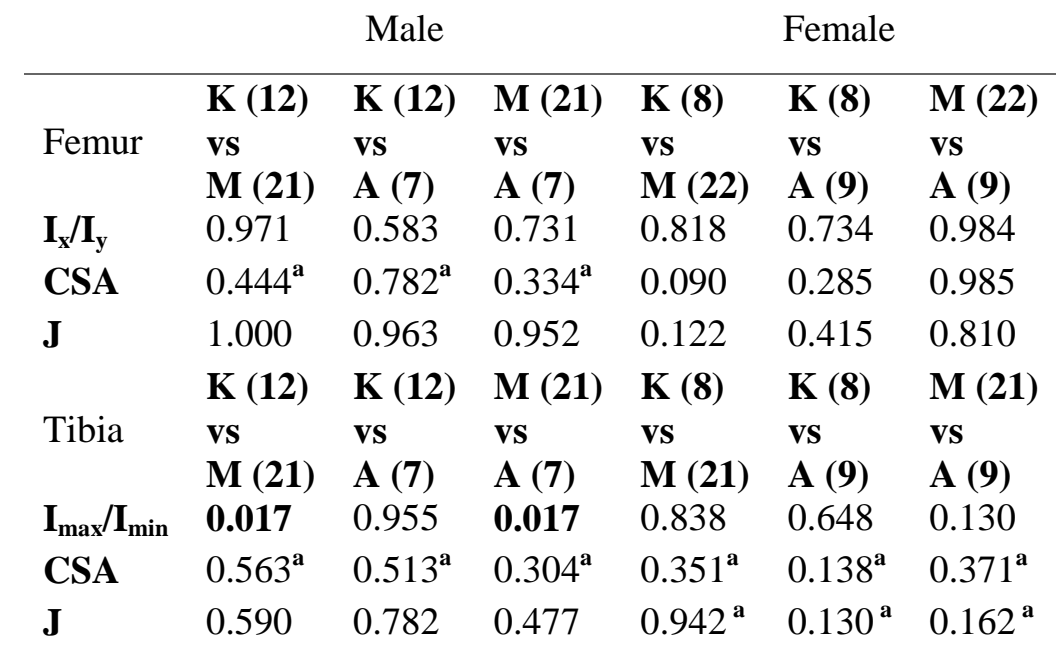


Table 4. T-test of Cross-sectional Properties between Males and Females and Dimorphism Index within Each Population for the Femur and Tibia. Significant results are in bold. CSA is standardized by dividing by body mass, and $J$ is standardized by dividing $J^{0.73}$ by the product of estimated body mass multiplied by bone length.

\begin{tabular}{|c|c|c|c|c|c|c|c|}
\hline \multirow[t]{2}{*}{ Femur } & \multirow[t]{2}{*}{ Variables } & \multicolumn{2}{|c|}{ Levene's Test } & \multicolumn{3}{|c|}{ t-test } & \multirow{2}{*}{$\begin{array}{c}\text { Dimorphism } \\
\mathbf{M} / \mathbf{F}\end{array}$} \\
\hline & & $\boldsymbol{F}$ & $p$ & $\mathbf{t}$ & df & $p$ & \\
\hline \multirow[t]{3}{*}{ Klaaskinderkerke } & $\mathrm{I}_{\mathrm{x}} / \mathrm{I}_{\mathrm{y}}$ & 0.938 & 0.346 & -0.494 & 18 & 0.628 & 0.96 \\
\hline & CSA & 1.255 & 0.277 & 3.099 & 18 & 0.006 & 1.15 \\
\hline & $\mathrm{J}$ & 0.810 & 0.380 & 2.165 & 18 & 0.044 & 1.18 \\
\hline \multirow[t]{3}{*}{ Middenbeemster } & $\mathrm{I}_{\mathrm{x}} / \mathrm{I}_{\mathrm{y}}$ & 4.433 & 0.041 & 0.790 & 33.3 & 0.435 & 1.05 \\
\hline & $\hat{C S A}$ & 3.250 & 0.079 & -0.260 & 41 & 0.796 & 0.99 \\
\hline & $\mathrm{J}$ & 1.389 & 0.245 & 0.644 & 41 & 0.523 & 1.03 \\
\hline \multirow[t]{3}{*}{ Alkmaar } & $\mathrm{I}_{\mathrm{x}} / \mathrm{I}_{\mathrm{y}}$ & 4.025 & 0.065 & 1.591 & 14 & 0.134 & 1.15 \\
\hline & CSA & 4.762 & 0.047 & 1.476 & 9.9 & 0.171 & 1.09 \\
\hline & $\mathrm{J}$ & 1.091 & 0.314 & 1.263 & 14 & 0.227 & 1.09 \\
\hline \multicolumn{8}{|l|}{ Tibia } \\
\hline \multirow[t]{3}{*}{ Klaaskinderkerke } & $\mathrm{I}_{\max } / \mathrm{I}_{\min }$ & 1.589 & 0.224 & 0.089 & 18 & 0.930 & 1.01 \\
\hline & CSA & 0.004 & 0.950 & 2.135 & 18 & 0.047 & 1.13 \\
\hline & $\mathrm{J}$ & 1.937 & 1.181 & 2.114 & 18 & 0.049 & 1.16 \\
\hline \multirow[t]{3}{*}{ Middenbeemster } & $\mathrm{I}_{\max } / \mathrm{I}_{\min }$ & 0.261 & 0.612 & 2.516 & 40 & 0.016 & 1.12 \\
\hline & CSA & 0.259 & 0.613 & 2.116 & 40 & 0.041 & 1.09 \\
\hline & $\mathrm{J}$ & 0.191 & 0.664 & 3.791 & 40 & 0.000 & 1.20 \\
\hline \multirow[t]{3}{*}{ Alkmaar } & $\mathrm{I}_{\max } / \mathrm{I}_{\min }$ & 0.939 & 0.349 & 0.643 & 14 & 0.531 & 1.05 \\
\hline & CSA & 0.077 & 0.785 & -1.594 & 14 & 0.133 & 0.81 \\
\hline & $\mathrm{J}$ & 0.127 & 0.727 & -1.078 & 13 & 0.301 & 0.86 \\
\hline
\end{tabular}


Table 5. Coefficients of Variation for Cross-sectional Properties. CSA is standardized by dividing by body mass, and $J$ was standardized by dividing $J^{0.73}$ by the product of estimated body mass multiplied by bone length.

\begin{tabular}{lllccccc} 
Bone & Sex & Population & $\boldsymbol{N}$ & $\mathbf{I}_{\mathbf{x}} / \mathbf{I}_{\mathbf{y}}$ & $\mathbf{I}_{\mathbf{m a x}} / \mathbf{I}_{\mathbf{m i n}}$ & $\mathbf{C S A}$ & $\mathbf{J}$ \\
\hline Femur & Male & Klaaskinderkerke & 12 & 15 & 18 & 10 & 23 \\
& & Middenbeemster & 21 & 23 & 11 & 9 & 16 \\
& & Alkmaar & 7 & 7 & 12 & 13 & 21 \\
& \multirow{3}{*}{ Female } & Klaaskinderkerke & 8 & 20 & 20 & 9 & 21 \\
& & Middenbeemster & 22 & 15 & 13 & 12 & 23 \\
Tibia & Male & Alkmaar & 9 & 24 & 16 & 10 & 15 \\
& & Klaaskinderkerke & 12 & 20 & 14 & 12 & 22 \\
& & Middenbeemster & 21 & 23 & 15 & 11 & 22 \\
& \multirow{3}{*}{ Female } & Alkmaar & 7 & 23 & 11 & 29 & 30 \\
& & Klaaskinderkerke & 8 & 15 & 12 & 13 & 16 \\
& & Middenbeemster & 21 & 24 & 14 & 14 & 23 \\
& & Alkmaar & 9 & 16 & 18 & 25 & 32
\end{tabular}

